\title{
EAMR
}

European Accounting and

Management Review

EUROPEAN ACCOUNTING AND MANAGEMENT REVIEW · VOL. 3, NO. 2, 65-74 MAY 2017

\section{Teaching transversal competences in the area of accounting: Fact or Fiction?}

\author{
Patricia Crespo \\ Ester Oliveras \\ Universitat Pompeu Fabra
}

Universitat Pompeu Fabra - Escola Universitaria del Maresme

Received March 1, 2017; accepted May 25, 2017.

\begin{abstract}
A high percentage of graduates in Economics and Business start a professional career in jobs related to accounting, auditing or finance. These areas have been characterized in recent decades by a large international as well as numerous financial scandals due to fraud and accounting manipulations. In Higher Education is necessary to ensure that key transferable skills are developed in the accounting subjects. The case method has been applied, by analyzing the accounting subjects of a Business Degree. The elements of the case are: syllabus analysis, faculty's opinion and actual practice and video recording of seminars. A detailed analysis shows that the transversal competences that are currently being taught and evaluated are oral communication skills and to a lesser degree written communication skills and teamwork. The ethical and social responsibility of the company is discussed tangentially through case studies in one compulsory subject. In this work we show in which areas there can be inconsistencies in the development and evaluation of transversals skills in higher education and specifically in the accounting area.
\end{abstract}

\section{KEYWORDS}

Evaluation, transversal competences, accounting.

JEL Codes: A23, M41, M42 


\section{Introduction}

Technological breakthroughs suggest that long-term graduates will get more out of a good foundation in transferable skills than in specific knowledge on a subject that becomes quickly outdated. Transferable skills are those that can be transferred to different situations and jobs, for example, good written communication. They are also called generic or soft skills.

Business degrees are taking into account the growing importance of generic skills and developing tools to develop them throughout the studies.

A recent survey shows that $50 \%$ of Catalan graduates start their career in accounting, auditing or financial institutions.

Career opportunities based in accounting, as in many other disciplines, have moved from a national approach to an international dimension. The growing importance of multinational corporations and international capital markets led to the emergence of European accounting standards (IAS/IFRS) which is rapidly spreading throughout the world, competing with the predominance of US-Generally Accepted Accounting Principles).

Additionally, financial scandals arising from accounting manipulations and fraud has compelled the approval of ethical codes and growing Corporate Social Responsibility programs as well as the proliferation of social companies focused on social needs instead of profit.

Given the weight of this area of knowledge within Business Studies, it is relevant to identify the most important transversal skills and compare it on how are the students actually trained.

The objective of this article is to identify inconsistencies between theoretical formulations, the perception of academics and what the classroom experience. In order to achieve this, first we review the literature and the most important professional associations of chartered accountants. Second, we interview academics about their practices within their subjects and contrast this with the official syllabus. 


\section{Generic skills in accounting}

(AQU Catalunya, 2014) and (AQU Catalunya, 2011) show that once in the workplace, Catalan graduated students in Business Studies perceive a lack of training in the following areas: languages, teamwork, critical thinking, oral and written communication and leadership. Similarly, (Accenture, 2007)affirms that "motivation, adaptability, quality orientation, communication skills and integration into a team" are the most important generic skills. More specifically, (Kavanagh \& Drennan, 2008) examine the differences between perceptions and expectations of two user groups: students and hiring companies. The results show that each group has a unique assessment of the most important skills. However, the common skills are: analytical skills and problem solving, oral and written communication, teamwork ability and capacity for continuous learning.

The importance of good communication skills and interpersonal skills have been vastly proven in several studies (Matis, Cuzdriorean, \& Vladu, 2011), (Johnson \& Halabi, 2011). Additionally, Anglo-Saxon countries are characterized by professional associations of accounting with a long history. For example, The Institute of Chartered Accountants in England and Wales (ICAEW), or The Institute of Chartered Accountants in Australia (ICAA).

All Accounting Professional bodies stress the importance of Ethics, using different formats. Just to name a few, for example, ICAEW has an exclusive web section centered on professional ethics with many resources available (case studies, webcasts, common ethical dilemmas and ethical code). The association Accountants and Financial Professionals in Business (IMA) has an Ethics Center. In Spain, AECA has published a Code of Ethics, and the Association of Chartered Accountants in Catalonia has an Ethics Committee. Given the importance of Ethics in professional accounting bodies it seems natural that accounting subjects included in business degrees should consider this generic skill as a priority.

However the translation of these professional requirements to university teaching has shortcomings. (Shah, 2013) shows that students do not enjoy working in groups, doing oral presentations or assessing peers. (Bunney, Sharplin, \& Howitt, 2015) (Johnson \& Halabi, 2011). 
Few years after the Bologna Declaration and after a severe economic crisis that has diminished the resources, we analyze a case study on how transversal skills are exposed in the syllabus and how are being taught in the accounting area.

\section{Case study}

We focused on the case of a specific Business Degree at an academic institution using qualitative and quantitative data. Each Degree has a Master Description that has been approved the competent authorities. According to that document the Degree has 9 accounting subjects: 5 compulsory subjects and 4 elective, all of them had a 5 ECTSworkload.

In Figure 1, there is the first consistency analysis. Firstly, we compared the transversal skills listed in the Master Description with those listed in the syllabus of each accounting subject. In that sense the level of congruence between documents was very high.

Secondly, we contrasted the transversal skills with the evaluation criteria included in the syllabus. In this relation, there are two inconsistencies:

- The transversals skills listed in the syllabus sometimes do not coincide with the skills actually being developed and evaluated. This is due to the rigidity of the Master Description of the Degree.

- The percentage of the mark given to the development and evaluation of transversal skills was not clearly specified. In the same line, the opinion of faculty is that they were evaluating the transversal skills but not differentiating academic content from transversal skills. 


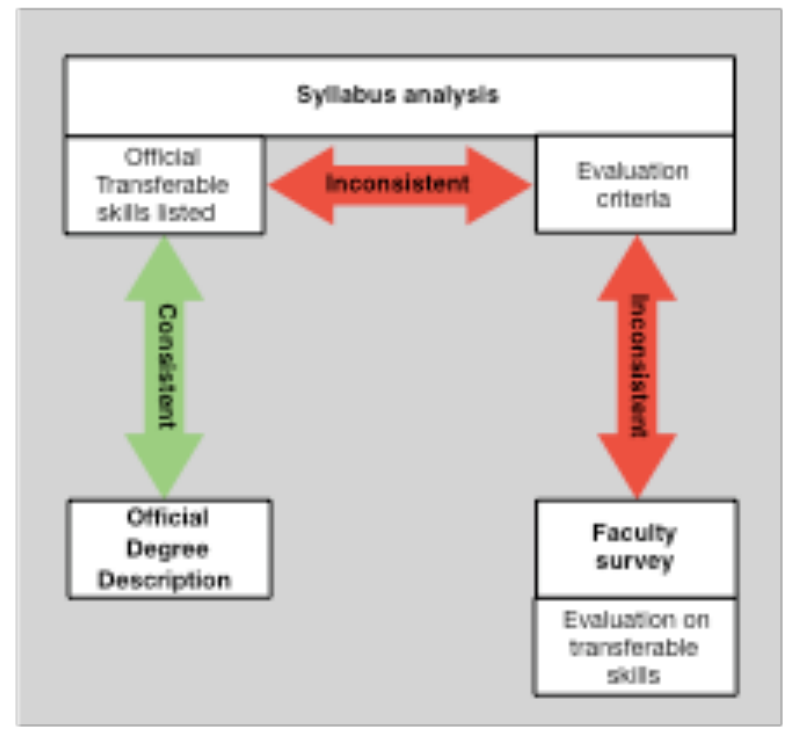

Figure 1. First consistency analysis

Moving on to the opinion of accounting faculty, the most important transferable skills would be of professional and technical character i.e. analytical skills and problem solving, critical capacity and synthesis as well as good numerical skills. Personal skills would be placed in fourth and fifth place: ability to learn in new situations and the ability to make decisions. Finally, interpersonal skills and communication character appear in the sixth position: ability to work in teams. Table 1 below shows the ranking of these skills:

\begin{tabular}{|l|l|}
\hline & Transferable Skills \\
\hline 1. & Analysis and problem solving \\
\hline 2. & Capacity of analysis, critical and synthesis \\
\hline 3. & Numerical skills \\
\hline 4. & Ability to learn and act in new situations \\
\hline 5. & Decision making \\
\hline 6. & Teamwork \\
\hline 7. & Capacity to generate new ideas and solutions \\
\hline 8. & Ethics \\
\hline 9. & Capacity to work autonomously \\
\hline 10. & Written communication skills \\
\hline 11. & Leadership \\
\hline 12. & Oral communication skills \\
\hline 13. & Negotiation skills \\
\hline
\end{tabular}

Table 1. Ranking on importance of transversal skills according to accounting faculty 
Next, in Table 2, there is the translation of the accounting faculty opinion to actual practices in the classroom. Transferable skills of professional and technical character are considered important, are being developed and they are being evaluated. However, moving down towards personal and interpersonal skills the level of inconsistency decreases. For instance, $60 \%$ of faculty stated that they develop the transversal skill of Ethics through case studies however it was not part of any assessment process. Also, as we mentioned in Figure 1 the percentages stated in the evaluation do not refer to the specific transversal skill it is mixed with the evaluation instruments such as the exam or projects.

\begin{tabular}{|l|c|c|}
\hline Transferable Skills & $\begin{array}{c}\text { Do you develop } \\
\text { this transferable } \\
\text { skill in the } \\
\text { subject? }\end{array}$ & $\begin{array}{c}\text { Do you evaluate this } \\
\text { skill? If so, in which } \\
\text { percentage? }\end{array}$ \\
\hline Analysis and problem solving & $100 \%$ & $100 \%$ \\
\hline Capacity of analysis, critical and synthesis & $90 \%$ & $80 \%$ \\
\hline Numerical skills & $100 \%$ & $100 \%$ \\
\hline Ability to learn and act in new situations & $50 \%$ & $30 \%$ \\
\hline Decision making & $80 \%$ & $40 \%$ \\
\hline Teamwork & $80 \%$ & $60 \%$ \\
\hline Capacity to generate new ideas and solutions & $60 \%$ & $40 \%$ \\
\hline Ethics & $60 \%$ & $0 \%$ \\
\hline Capacity to work autonomously & $50 \%$ & $30 \%$ \\
\hline Written communication skills & $90 \%$ & $90 \%$ \\
\hline Leadership & $10 \%$ & $0 \%$ \\
\hline Oral communication skills & $50 \%$ & $50 \%$ \\
\hline Negotiation skills & $10 \%$ & $0 \%$ \\
\hline Table 2. Perceived faculty actions & \\
\hline
\end{tabular}

Table 2. Perceived faculty actions in relation to transferable skills

In Table 3, there is the third analysis which consisted in looking at the assessment methodologies listed in the syllabus and which transversal skills can be developed according to the usage of those methodologies. The results shows that more than $50 \%$ of compulsory subjects are evaluated through multiple choice exams, leaving oral 
communication skills at only $8 \%$ of the mark. This trend is reversed during the elective subjects, in those the development of practical cases in an individual base becomes very high, at $63 \%$. Therefore, leaving aside the transferable skills that are interlinked with the nature of the area of knowledge i.e. professional and technical character, there are only three transferable skills left: written and oral communication and teamwork.

\begin{tabular}{|c|c|c|c|c|c|c|c|}
\hline & $\begin{array}{l}\text { Multiple } \\
\text { choice }\end{array}$ & $\begin{array}{c}\text { Practical } \\
\text { case } \\
\text { individual }\end{array}$ & $\begin{array}{l}\text { Practical } \\
\text { case } \\
\text { group } \\
\text { (seminars) }\end{array}$ & $\begin{array}{c}\text { Oral } \\
\text { Presentation }\end{array}$ & $\begin{array}{c}\text { Open } \\
\text { theoretical } \\
\text { questions }\end{array}$ & Project & Other \\
\hline $\begin{array}{l}\text { Compulsory } \\
\text { subjects }\end{array}$ & $51 \%$ & $19 \%$ & $10 \%$ & $8 \%$ & & $10 \%$ & \\
\hline $\begin{array}{l}\text { Elective } \\
\text { subjects }\end{array}$ & $9 \%$ & $63 \%$ & $11 \%$ & $5 \%$ & $10 \%$ & 0 & $3 \%$ \\
\hline \multirow{3}{*}{$\begin{array}{l}\text { Transferable } \\
\text { skills }\end{array}$} & APS & APS & $\mathrm{T}$ & $\mathrm{OC}$ & $\mathrm{WC}$ & $\mathrm{WC}$ & \\
\hline & $\mathrm{N}$ & $\mathrm{N}$ & & & & $\mathrm{T}$ & \\
\hline & & & & & & $\mathrm{CACS}$ & \\
\hline
\end{tabular}

Table 3. Evaluation criteria and transferable skills in compulsory and elective subjects. (APS $=$ Analysis and problem solving, $\mathrm{OC}=$ Oral Communication, $\mathrm{WC}=$ Written Communication, $\mathrm{CACS}=$ Capacity of analysis, critical and synthesis, $\mathrm{N}=$ Numerical, $\mathrm{T}=$ Teamwork)

In our fourth analysis, there was a closer look to those subjects that actually develop the following transversal: written communication, oral communication and teamwork. Regarding the development of written communication skills the assessment is as follows:

- In Financial Statement Analysis there is the development of a 40 pages project written in a 5 person-group.

- Theoretical questions in exams only appear in Financial Statement Analysis and International Financial Accounting (elective), these are short written communications not exceeding a page length.

Oral communication skills are developed in the following subjects:

- Financial Statement Analysis. Students present a case study in groups and then receive written qualitative feedback from peers. The teacher carries out final assessment.

- Cost Accounting I solves a case in group. Teacher assessment. 
- International Financial Accounting (elective): Pedagogical material on oral communication is made available to the students. The assessment is an average between peers and faculty. The assessment is broken down under seven rubrics taking into account both verbal and nonverbal aspect. It should be noted that this subject has received advice from the Center for Teaching Quality UPF to improve the development of oral skills.

Finally, regarding the teamwork skill:

- In all accounting subjects the students choose with whom to work. No attention is paid to increase diversity.

- In the video recording of Auditing seminars the main observations was that students always work with the same persons to solve numerical cases, sometimes without talking too much between them.

- In Financial Statement Analysis the development of the project requires higher interaction and the students must agree on the amount of project inputs (measured in percentage) for each group member.

For the rest of transversal skills although faculty state that they are developing and evaluation those competences it cannot be extrapolated from the reading of the syllabus or the evaluation methodology.

\section{Conclusions}

The first conclusion is the existence of a mismatch between listed transversal skills in the syllabus and the transversal skills actually developed during the subjects. This is due to the rigidity of the Degree Master Description. Secondly, most transversals skills are not being evaluated separately. In the evaluation instrument specific and transversal skills are mixed and not being specific weights. Thirdly, the perception of faculty is that they are developing and evaluating many transversal competences but it is not shown in the syllabus or in the evaluation process.

However, the level of inconsistency varies depending upon the transversal skills. There is good consistency in professional and technical skills and in oral communication, but mainly in the elective subjects, as we can see in Figure 2. 
The level of consistency decreases in the skills of teamwork, written communication and capacity of analysis and finally is clearly deficient in the rest of transversal skills.

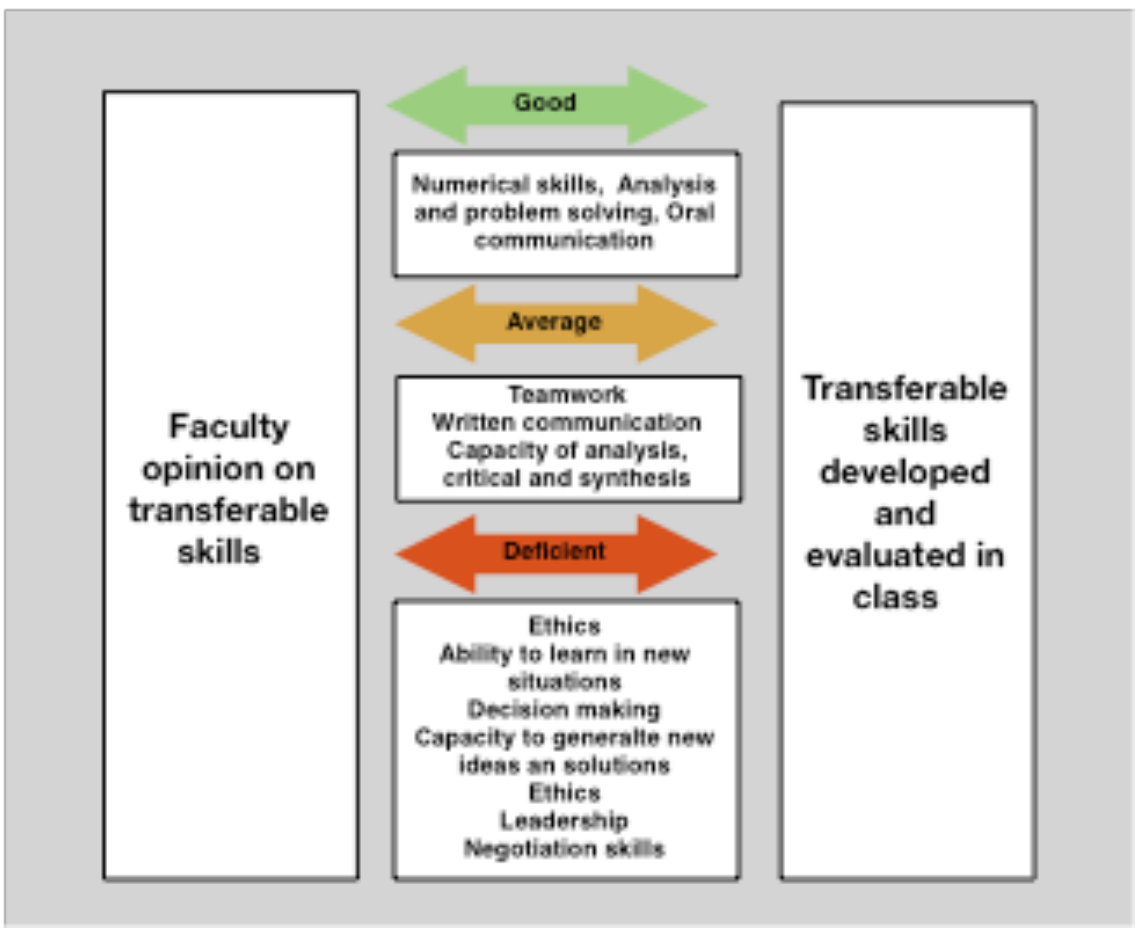

Table 4. Second consistency analysis

This model is a useful tool to identify inconsistencies and take corrective action in syllabus. Additionally, it can become a pedagogical tool for faculty members regarding the development and assessment of transversal skills on their subjects.

A further line of research is to explore ${ }^{\mathrm{i}}$ how faculty members perceive the development and evaluation of transversal skills, and identify additional formative pedagogical aspects. 


\section{REFERENCES}

Accenture. (2007). Las competencias profesionales en los titulados. Contraste y diálogo Universidad-Empresa Presentación final de resultados. Retrieved from http://www.unizar.es/ice/images/stories/calidad/EstudioCompleto.pdf

AQU Catalunya. (2011). Universitat i treball a Catalunya 2011.

AQU Catalunya. (2014). Universitat i treball a CatalUnya 2014 Estudi de la inserció laboral de la població titulada de les universitats catalanes.

Bunney, D., Sharplin, E., \& Howitt, C. (2015). Generic skills for graduate accountants: the bigger picture, a social and economic imperative in the new knowledge economy. Higher Education Research \& Development, 34(2), 256-269.

http://doi.org/10.1080/07294360.2014.956700

Johnson, G. F., \& Halabi, A. K. (2011). The accounting undergraduate capstone: Promoting synthesis, reflection, transition, and competencies. Journal of Education for Business, 86(August 2015), 266-273. http://doi.org/10.1080/08832323.2010.514013

Kavanagh, M. H., \& Drennan, L. (2008). What skills and attributes does an accounting graduate need? Evidence from student perceptions and employer expectations. Accounting and Finance, 48(2), 279-300. http://doi.org/10.1111/j.1467629X.2007.00245.x

Matis, D., Cuzdriorean, D., \& Vladu, B. (2011). Specific and General competencies regarding tax and accounting for economic graduates - employers opinion. In EDULEARN11 Proceedings (pp. 4516-4523). International Association of Technology, Education and Development (IATED).

Shah, S. Z. A. (2013). The use of group activities in developing personal transferable skills. Innovations in Education and Teaching International, 50(3), 297-307. http://doi.org/10.1080/14703297.2012.760778

\footnotetext{
${ }^{\text {i }}$ Project financed by PlaQUID 2014-15, Universitat Pompeu Fabra.
} 